\title{
ANALYSIS OF THE IMPLEMENTATION OF MONEY LOAN TRANSACTION BUSINESS IN MITRA BISNIS KELUARGA VENTURE ACCORDING TO ISLAMIC ECONOMICS
}

\section{ANALISIS IMPLEMENTASI TRANSAKSI PEMINJAMAN UANG PADA MITRA BISNIS KELUARGA (MBK) VENTURA BERDASARKAN EKONOMI ISLAM}

\author{
L. Aulia'a; K. Nawawi²; T. Suhandi ${ }^{3}$ \\ 1aProgram Studi Ekonomi Syariah Fakultas Agama Islam Universitas Ibn Khaldun, Jalan \\ KH Sholeh Iskandar KM.2, Kedung Badak, Tanah Sereal, Jawa Barat 16162, e-mail: \\ auliatunnissa47@gmail.com \\ ${ }^{2}$ Program Studi Ekonomi Syariah Fakultas Agama Islam Universitas Ibn Khaldun, Jalan \\ KH Sholeh Iskandar KM.2, Kedung Badak, Tanah Sereal, Jawa Barat 16162, e-mail: \\ kholil@fai.uika-bogor.ac.id \\ ${ }^{3}$ Program Studi Ekonomi Syariah Fakultas Agama Islam Universitas Ibn Khaldun, Jalan \\ KH Sholeh Iskandar KM.2, Kedung Badak, Tanah Sereal, Jawa Barat 16162, e-mail: \\ tjetjep@fai.uika-bogor.ac.id
}

\begin{abstract}
This study aims to find out how the review of Islamic Economics is seen from the contract in accordance with sharia principles on the implementation of loan transactions for Venture Family Business Partners in Situ Udik Village, Cibungbulang District, Bogor. This type of research is descriptive qualitative research with exposure related to existing problem solving. The results of this study indicate, according to the review of Islamic Economics, seen from the analysis of the contract, the MBK Ventura money loan does not use a contract that is in accordance with sharia principles but uses the Grameen Bank system. Grameen Bank is the provision of unsecured loans that are devoted to the poor. This $20 \%$ profit sharing shows an additional loan from MBK Ventura's capital money for MBK Ventura itself. $20 \%$ is said to contain elements of usury, because in practice there is no contract in accordance with sharia principles. From the community response, it was shown that, successful or unsuccessful in using money for business capital, still had to pay a return on capital with an additional $20 \%$. Thus, the implementation of the MBK Ventura money loan transaction is not permitted in Islam, because there is an addition to each loan including usury.
\end{abstract}

Keywords: Islamic Economics, Venture Capital, Financial Systems

\section{ABSTRAK}

Penelitian ini bertujuan untuk mengetahui pandangan Islam terhadap implementasi transaksi pinjaman pada mitra bisnis keluarga ventura berdasarkan padangan ekonomi Islam di desa Situ Udik, Kecamatan Cibungbulang Bogor. Penelitian ini adalah penelitian 
kualitatif dengan penekanan pada penyelesaian masalah. Hasil penelitian berdasarkan pandangan Islam menunjukkan bahwa MBK tidak menggunakan kontrak atau akad yang sesuai dengan shariah Islam tetapi lebih mengadopsi sistem Grameen Bank. Grameen Bank adalah sistem pinjaman uang yang ditujukan untuk orang miskin. Dua puluh persen keuntungan yang diperoleh diberikan untuk MBK 20 persen keuntungan tersebut mengandung unsur ribawi yang tidak sesuai dengan syariah Islam. Berdasarkan hasil wawancara masyarakat menyatakan bahwa kelebihan 20 persen terhadap MBK harus dibayarkan meskipun bisnis yang dijalankan mengalami keuntungan ataupun tidak. Praktik peminjaman uang oleh MBK termasuk dalam transaksi yang dilarang dalam Islam karena mengandung ribawi.

Kata Kunci: Ekonomi Islam, Modal Ventura, Sistem keuangan.

Aulia, Lia. 2018. Analysis of The Implementation of Money Loan Transaction Business Partner Ventura Family According By Islamic Economy. Jurnal Syarikah 4 (2): 99107.

\section{INTRODUCTIONS}

Economic activity is a human character to fulfill his life's needs, with this activity he can obtain sustenance and with that sustenance he will continue his life. For muslim Quran is a guide to fulfill the absolute truth and sunnah of the Prophet Muhammad functioned to explain the contents of Quran. There are many verses of Quran and Hadith recommen people to work diligently. Every individual can do any work as long as she/he doesn't break Islamic LAW, including in economic activity. Never the less, not all economic activities are justified by the Qur'an and Hadith such as trade monopolies, brokers, gamblers, and usury, it will definitely be rejected by Islam. This economics activity forbiden because of the activity just give benefits only for small number of people.

In everyday life, theres always economic activity. Transaction happen every where with or unnoticed that namely ariyah (loan). There were many incidents of disputes in the society between loan and financing. This happens because of an incomprehension between the right and obligation lender and borrower.

In Indonesia, access to loans through formal financial institutions (LK) is still in low percentage. A recent survey from the World Bank shows that only $13.1 \%$ of Indonesians borrow from formal financial institutions. About 41.5\% of Indonesians borrow from informal institution such as family or friends to meet their loan needs, this is an astounding percentage. Microfinance service providers such as venture capital FIs, cooperatives and BPRs that offer modified grameen method loans, observe this gap and develop their business rapidly in recent years in Indonesia.

The main findings in loan sources: FIs (99\%), loan sharks (86\%), and banks $(47 \%)$ are the main providers of loans to community members. Financial 
Institutions have a high percentage because our main respondents are LK loan customers. The existence of other informal sources such as moneylenders (86\%), friends / family (31\%) and arisan (23\%). Loans from these informal sources can be obtained quickly, easily and only require documents that are minimal or without documents at all.

The life cycle,capitalization in business is very important, because capital linked with business movements. The smaller the capital has then the more limited business movement, especially for traditional market traders. Capital constraints can restrain the opportunity to get optimal income to maintain survival their business. However, due to several factors, such as complicated administration if you have to borrow money from a bank or microfinance institution, whether it is conventional or shari. At the end of this condition makes traders from traditional markets trapped in informal financial institutions; moneylenders.

In the West Java Garut at the year 2016, were people get problems because of moneylender under the guise of MBK, where MBK was a moneylender that impersonate as a financial institution conducting usury which was forbidden by Allah SWT. The community feels disadvantaged by the existence of MBK., eventhough it used a moneylender system, but many people were still deceived by the existence of moneylenders under the guise of MBK.

In Islam, lending and loan is not prohibited, it even recommended that mutually beneficial relationships occur, which in turn result in brotherly relations. Therefore, related parties must follow the ethics outlined by Islam.

Today many people are in desperate need of money to fulfill their needs. They can do all kinds of ways to meet their needs, as happened in Situ Udik Village, Cibungbulang Sub-district, which loans Mitra Bisnis Keluarga (MBK) money. This MBK loan has been going on for around 10 years, and once a week the community gathers, especially mothers to make promises every time the deposit and when there is one person who is unable to pay, this will be the group's responsibility. MBK loans are loans that have long been in the community of Kp. Pasir Putih Rt 01/11, but the majority of the community still do not know where MBK came from, and are still confused about the Islamic law on this MBK loan because there may still be a lack of knowledge.

\section{LITERATURE REVIEW AND RESEARCH METHODS}

\section{Definition of Loan and Legal Basis Loan}

Loans in Arabic languages are 'ariyah. In the concept of 'ariyah there must be no material benefits or benefits for the person who lent it. While loans in terms of jurisprudence to show the act of loan, as one of the activities between humans. In the implementation of 'ariyah, it is defined as the act of giving property temporarily by someone to another party. Lending and loan transactions can be carried out with the willingness of a sincere heart. Islam recognizes the need for things that are shown by the suggestion to be socially loving. 
Ariyah can be obligatory on someone who has the advantage of assets to lend it to someone who is in dire need. If the person is not given a loan, causes him to be persecuted or will do something that is prohibited by religion, such as he stole because there is no cost to fulfill his needs his life. Because Islam encourages its followers to always help in goodness, this is based on the word of Allah the letter Al-Maidah verse 2, that is:

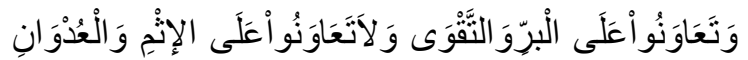

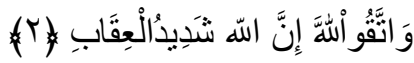

"And please help in doing virtue and piety, and do not help in committing sin and transgression" (Q.S.Al-Maidah: 2).

\section{Kinds of contracts in Sharia KTA (Unsecured Credit) loans}

1. Murabahah

Murabahah buying and selling contract is one form of contract in financing based on buying and selling (Bai). Murabahah is currently widely used by Islamic banking in financing products. The application of the murabahah contract to Islamic banks is that the Islamic bank becomes the second party (seller) of the object the debtor wants. Then the bank will sell the item (it can be a car, motorcycle, gold, house etc.) to the customer with a certain margin (as long as it is within reasonable limits).

2. Ijarah Wa Iqtina

Islamic money loans not only recognize the murabahah contract, but also the Ijarah wa iqtina contract. The application of this contract is carried out in which the Sharia Bank will buy the item the customer wants, but the customer first rents the item for a certain period of time. After a certain period of time ends, you can buy the item.

The application of the Ijarah contract on Islamic Bank loan products does not apply to consumptive financing on the purchase of goods. This contract is also applied in financing a service. For example in consumptive financing to meet the need to purchase Hajj and Umrah services. In general, Islamic banks work with travel agents.

3. Mutanaqishah

The last contract used in the Islamic loan is Mutanaqishah. The application of this contract is used as a system of capital join. Mechanism of this product in Islamic Banks and customers both provide capital in a matter (eg business. Examples of Islamic Banks finance 70\% and customers finance to buy the latest motorbikes. Furthermore, so that customers can have a full motorbike, customers can buy Sharia-owned shares.

\section{Legal Advantages of Loan Payment}

Transaction and loan money is a good and effective way of trading. In this case it can be based on the fact that the bank, for example, bases its business on lending and loan money for capital, and that it is seen as something that can support the growth and national economy.

Loan and lending money in Islam is not something that is not permissible, even the Islamic Shari'ah gives very sympathetic rules in the debt owed. This can be seen in Sura Al-Baqarah 282 and 283. The existence of these texts seems to be sufficiently convincing that indebtedness is not prohibited, but it can be seen that the issue of interest is not mentioned at all. But this absence cannot be said to be due to Allah's forgetfulness, 
because Allah is all-knowing and it is impossible for him to forget. Similarly, it cannot be said that interest cannot arise from owing accounts. Reality refers to that interest arises from transactions owing to receivables.

Interest on debts is not mentioned in QS.Al-Baqarah 282-283 which have been mentioned earlier, but in previous texts, starting from QS Al Baqarah 275280 have been regulated and warned and strictly prohibited about usury. Interest and usury can both arise from debts owned, therefore loan money can be seen as one of the bases for interest and usury, and interest can also arise from the following:

1. Loan and loan money between someone and someone else.

2. Borrow money and save to banks or other credit markets.

3. By buying shares or bonds of a company.

\section{Definition of Sharia Venture Capital}

The term venture comes from the word venture which can mean something that contains risk or can also be interpreted as business. Thus, the language of venture capital (venture capital) is capital invested in a business that contains risks. Sharia Venture Capital is an investment carried out by an Islamic financial institution for a specified period of time, and after that the financial institution divests or sells its share to the company's shareholders. Venture capital financing in the early stage of life of an investee is a classic form of musyarakah or mudarabah financing. From an Islamic point of view, the use of equity financing in the form of shares or limited participation with profit sharing is a form of the application of mudarabah, musyarakah'inan or musyarakah'inan almutanakissa. The close relationship between providers of funds and users of funds, ranging from the stipulation of clauses concerning the use of funds to add value, monitoring, and sharing of results and risks in accordance with the spirit of musharaka.In terms of Islamic financing it is confirmed that it is very feasible to apply with venture capital. As is known there are three main Islamic financing instruments, namely:

1. Musharaka. This financing is useful for business or project independence. Musyarakah financing is mixed with funds to establish a new business or project contract with the aim of being able to make a profit. The owner of capital in musharaka financing is a venture capital company, an entrepreneur or can be a non-active business partner. The advantages and disadvantages of this project are enjoyed together in accordance with the existing portion with the concept of profit or loss sharing.

2. Mudarabah, useful for financing businesses or projects that can be aligned with bond instruments. The company holds the mandate received by venture capital companies where the available capital is a deposit with a wadiah scheme that can be used to make a profit.

3. Murabahah financing is the sale and purchase of goods for investment purposes and also the raw materials used for the benefit of working capital.

Sharia venture capital is a financing business in the form of equity participation in a company that receives financing assistance for a certain period of time based on sharia principles. The 
practice of venture capital is based on a sharia contract, and moves in a business that does not conflict with sharia principles. Characteristics of venture capital financing include: capital investment, which is a high-risk financing, an investment with a long-term perspective, active investment, temporary. Expected profits are mainly capital gains in addition to dividends, high profit levels. The characteristics of Islamic venture capital companies coupled with the existence of the Sharia Supervisory Board, business activities must be in accordance with sharia principles. The mechanism of venture capital is a process that describes the flow of investment that starts from the entry of investors by forming a pool of funds, the process of financing the business partner company until the process of withdrawal of the investment (divestment).

\section{Research methods}

Judging from the data used, the research approach used in this study is a qualitative approach. As for what is mean qualitatively is research to understand the phenomenon of what is experienced by the research subject, and by way of description in the form of words and language (LexyJ and Moleong, 2005 p. 6)..

From this study, the authors took a sample of 25 people or $5 \%$ of the population of 500 people. To obtain data from the field, researchers used methods in data collection, namely observation, interviews, and questionnaires conducted on July 25, 2018. The analysis method using case study. This field research was used to reveal, describe and describe a problem in the analysis of the implementation of MBK Ventura money loan transactions according to Economic review Islam. This research site is the office of the Situ Udik Village, Cibungbulang District, Bogor.

\section{RESEARCH RESULT \& DISCUSSION}

PT MBK (Mitra Keluarga Keluarga) is a company engaged in microfinance. PT. MBK was established on September 19, 2003, while the Bogor Branch was established on September 19, 2006. The purpose of the establishment of this company was to encourage the development of micro and small businesses for poor families. PT MBK provides loan or credit services to the community (especially for women from underprivileged families), especially in rural areas without guarantees or guarantors, on the basis of mutual trust, participation, accountability, transparency, support and influence from others. One of them is the Situ Udik Village, Cibungbulang District, Bogor.

The loan process for MBK Ventura money is carried out by some people in Kp. Pasir Putih Desa Situ Udik turned out to have been going on for quite a long time, for 10 (ten) years. The people who participated in the MBK loan collection were \pm 25 people in each group. Every once a week, women gather to make deposits every Monday at 11.00 to 11.30 WIB. In the implementation of the MBK loan transaction when it was already underway, the people of the women who took part in the MBK money loan had to sit neatly without speaking, except to make promises that were often made when the gathering took place. Every Monday they gather and make promises that I find funny are endless. Their promises say "members' promises, be 
present on time, deposit every week, business approved by friends, business results for the family, joint responsibility and willing to invite friends who are stuck paying." But when the funds were disbursed, there were customers who did not join the collection weekly, the disbursement will be canceled. So when it's time to withdraw funds, customers are required to gather all without exception. This loan transaction for MBK money was carried out in one of the houses of the residents of Kp. Pasir Putih Village RT 01/11.

The process of the MBK loan transaction took place at the beginning, the officer from PT MBK provided a capital loan of Rp.500.000 and repaid 50 weeks until the loan repayment was paid off. From customer data, there were several ladies who borrowed MBK in the amount of Rp. 1.200.000-Rp. 3.000.000. I also asked the community or customers who took part in the MBK money loan which had small shops. Let's say the name is Mrs. Nita, this customer borrows money from MBK for Rp.2.500.000. installments every week amounting to $\mathrm{Rp}$. 60.000 / week and repayments for 50 weeks until the repayment of the loan is paid off. So from the payment of IDR $60.000 \times 50$ weeks $=$ IDR 3.000.000. the loan capital that must be returned by the customer is IDR 3.000.000 per year (50 weeks).

Can be calculated by the formula:

$$
\begin{aligned}
& \text { Bagi hasil } \quad=\mathrm{B} \% \times \mathrm{M} \times \mathrm{T} \text { (Year) } \\
& =20 \% \times \text { Rp. } 2.500 .000 \times 1 \\
& =20 \% \times \text { Rp. } 2.500 .000 \\
& =0.5 \text { or Rp. } 500.000 \\
& \text { Total }=\text { Capital }+ \text { Results } \\
& =\text { Rp. } 2.500 .000+\text { Rp. } 500.000 \\
& =\text { Rp. } 3.000 .000
\end{aligned}
$$

So, capital and profit must be paid in the amount of Rp. 3.000.000 for 1 (one year), and the results of the MBK Ventura money loan transaction were $20 \%$ in each loan.

It can be seen in the table of provisions for repayment of capital loans on MBK Ventura money loan transactions below:

\begin{tabular}{|l|l|l|l|l|}
\hline No & $\begin{array}{l}\text { Loan of } \\
\text { Capital }\end{array}$ & $\begin{array}{l}\text { Weekly } \\
\text { Payment }\end{array}$ & $\begin{array}{l}\text { Amount of } \\
\text { Week }\end{array}$ & $\begin{array}{l}\text { Return of } \\
\text { Loan }\end{array}$ \\
\hline 1. & $\begin{array}{l}\text { Rp. } \\
1.000 .000\end{array}$ & Rp. 2.4000 & 50 & $\begin{array}{l}\text { Rp. } \\
1.200 .000\end{array}$ \\
\hline 2. & $\begin{array}{l}\text { Rp. } \\
1.500 .000\end{array}$ & Rp. 3.6000 & 50 & $\begin{array}{l}\text { Rp. } \\
1.800 .000\end{array}$ \\
\hline 3. & $\begin{array}{l}\text { Rp. } \\
1.800 .000\end{array}$ & Rp. 43.200 & 50 & $\begin{array}{l}\text { Rp. } \\
2.160 .000\end{array}$ \\
\hline 4. & $\begin{array}{l}\text { Rp. } \\
2.500 .000\end{array}$ & Rp. 60.000 & 50 & $\begin{array}{l}\text { Rp. } \\
3.000 .000\end{array}$ \\
\hline 5. & $\begin{array}{l}\text { Rp. } \\
4.500 .000\end{array}$ & $\begin{array}{l}\text { Rp. } \\
10.8000\end{array}$ & 50 & $\begin{array}{l}\text { Rp. } \\
5.400 .000\end{array}$ \\
\hline
\end{tabular}

In addition to each return on capital, which is $20 \%$ for 1 (one) year, judging from the customer's perception of using money for business capital, whether the customer is successful or not, the $20 \%$ percent must still be paid when returning the capital. So, this is detrimental to one party, not just the welfare of customers, but harms customers.

According to the review of Islamic Economics, judging from the suitability of the contract and the payment recapitulation, there is no contract in accordance with sharia principles, because when there is no contract in the MBK Ventura loan transaction, such as the mudarabah contract in a joint agreement, the result is adjusted to the business profit and loss customer. As such, the results used in MBK Ventura loan transactions include usury, but not profit but interest, because they harm one party. And the addition of any return on 
the legal capital loan is usury. In the Qur'an, it has been explained:

the rules that scholars agree on this issue read,

$$
\text { كُل قَرِْْ جَرَنَنْفَاَفَهُوَرِبَ }
$$

"Every loan that generates benefits is usury"

\section{CONCLUSION AND IMPLICATIONS}

\section{Conclusion}

The conclusion obtained in this study is that in practice, there is no contract in the implementation of the MBK Ventura money loan transaction, but rather uses the Grameen Bank system, namely the provision of unsecured loans specifically for the poor.

The public perception of the MBK Ventura money loan transaction in Situ Udik Village, Cibungbulang District is the majority, not all of them know about the MBK system and where MBK came from. Because they really need to borrow MBK money, money borrowed from MBK Ventura for additional trading capital, when they have done MBK Ventura's loan money the community feels mediocre, in using the capital from MBK Ventura for the majority business in its business, sometimes it works, the majority of people do not know how Islamic law is about MBK Ventura's loan money transactions, and in determining the percentage of profit sharing stipulated in the MBK Ventura money loan transaction, the community feels mediocre.

According to the review of Islamic Economics, the implementation of MBK Ventura money loans in Situ Udik Village is not permitted, because there is an additional in every return on capital loans which is $20 \%$ and that includes usury even though PT MBK Ventura uses profit sharing, but in practice there is no contract in accordance with Sharia principles used in MBK Ventura's loan transactions to customers. According to Islamic law the addition of each loan contains elements of usury, and usury is unlawful.

\section{REFERENCE}

Al- Qur'an Al- Karim dan Terjemah

Al- Hadis

Antonio, Muhammad Syafi'i. 2001. Bank Syariah: dari teori ke praktik. Jakarta: Gema Insani.

Chaudry, Muhammad Sharif. 2014. Sistem

Ekonomi Islam (Prinsip Dasar). Jakarta: Kencana Prenadamedia Group. cet ke-2, h.77.

Devi Abrista dan Hendri Tanjung. 2013. Metodologi Penelitian Ekonomi Islam. Jakarta: Gramata Publishing.

Huda Nurul dan Muhammad Heykal. 2010. Lembaga Keuangan Islam. jakarta: prenada media group.

Ibdalsyah dan Tanjung Hendri. 2014. Fiqh Muamalah (Konsep dan praktek). Bogor: Azam Dunya Bogor.

Karim, Helmi. 2002. Fiqh Muamalah. Jakarta: PT. Raja Grafindo.

Meleong, J Lexy. 2005. Metodologi Penelitian Kualitatif. Bandung: Remaja Rosdakarya.

Soemitra, Andri. 2010. Bank Lembaga Keuangan Syariah. Jakarta: Kencana. Sabirin, Sabirin. 2017. Islamic Micro Finance: Fighting Moneylenders (A Capital Strengthening Efforts for Traditional Market Traders). Jeremia Persadanta Home, Vol 1, No 1. 
Nurhidayati. 2012. "pelaksanaan transaksi pinjaman uang kepada rentenir di Desa Karya Indah". Skripsi. Universitas Islam Negeri Sultan Syarif Kasim Riau.

www.pakindo.org. 2016. studi pinjaman berlebih di Indonesia "mengapa nasabah mikro mengambil banyak pinjaman?", diakses pada tanggal 5 Oktober 2016.
FOKUS Jabar.com. 2016. Rentenir Berkedok MBK. diakses pada tanggal 11 Januari

Panduan bank.com. 2018. diakses pada tanggal 27 April 2018 pukul 13.00 WIB

www. MBK Ventura.com diakses pada Januari 2018. 